\title{
Factors Responsible for Adoption of Improved Pea Production Technology among the Pea Growers
}

\author{
Tiwari Abha*, Markam Neha and M.K. Dubey \\ Jabalpur district of Madhya Pradesh, India \\ *Corresponding author
}

\section{A B S T R A C T}

Keywords

Pea, Adoption behavior, Pea growers

Article Info

Accepted:

10 February 2019

Available Online: 10 March 2019
The present study is designed to know whether the pea growers are adopting these recommendations or not and upto what extent. The study will also critically find out the main impediments in adoption of the technology. The present study has been designed to analyze the adoption behaviour of pea growers of Shahpura and Patan blocks of Jabalpur district. Characteristics of pea growers like age, education, caste, size of land holding, farm power, area covered under pea crop, experience of pea growing, annual income, social participation, knowledge level, scientific orientation, training needs, extension participation, source of information, marketing orientation. It was observed that the majority of pea growers had low knowledge level and low adoption behaviour.

\section{Introduction}

Pea (Pisum sativum L.) family Leguminaceae is one of the important vegetable and pulse crops of India. Mostly grown as winter crop grain legume crop largely confined to cooler temperature zones. Pea mostly cultivated as garden pea (Pisum sativum var, hortance) and the field pea (Pisum sativum var., arvence). The garden pea is used for table purpose, harvested as green pod, while the field pea is round or dimple seeded and used as pulse whole or splits. It is the inseparable ingredient of vegetarian diet and is the cheapest source of dietary protein $(22.5 \%)$, carbohydrate $(62.1 \%)$, fat $(1.8 \%)$, vitamins (riboflavin, thiamin etc.) and minerals (calcium iron). It is also grown as a forage crop for cattle or as a cover crop to reduce soil erosion. Pea is an important forest hardy, cool season, nutrious leguminous vegetable.

Green pea or vegetable pea are eaten cooked as a vegetable and are marketed fresh, canned or frozen. The green pea (Pisum sativum L.) variety hartense is a green coloured, wrinkled seeded, sweet in taste, young green pods re plucked and sold in the market which gives an attractive price. Presently, peas are grown for processing, fresh wholesale and direct to consumer markets. Markets are potentially available for production of specially crops like 
edible podded pea. These markets are limited due to the requirement for hand picking though the market demand is high. Pea is cultivated in an area about 10 million hectares in the world. The major pea growing countries are USSR, China, France, Australia, USA and India. In India, it is grown in Uttar Pradesh, Madhya Pradesh, Bihar, Assam, Orissa and Rajasthan, which together share as much as 475.89 thousand hectares total area and contribute 4651.53 metric tons the total production of this crop (National Horticulture Board, 2014-15).

Madhya Pradesh is the second largest pea producer state in India. Pea is grown over an area of 57.80 thousand hectares with a production of about 607.00 metric tons. The productivity of pea is about $1050.17 \mathrm{~kg} / \mathrm{ha}$ (National Horticulture Board, 2014-15). Jabalpur is the largest pea producing district in Madhya Pradesh and largely cultivated in Patan and Shahpura block of the Jabalpur district of M.P. It is recorded from the available secondary data that the production of pea crop in Shahpura and Patan blocks is 9600 metric tons, whereas the area under this crop in the Shahpura and Patan blocks is 1600 ha. In order to obtain optimum yield of pea crop, the present study is designed to know whether the pea growers are adopting these recommendations or not and upto what extent. The study will also critically find out the main impediments in adoption of the technology.

The present study has been disigned to analyze the Factors responsible for adoption of improved pea production technology among the pea growers of Shahpura and Patan blocks of Jabalpur district to fulfill the following specific objectives:-1. To determine the adoption behaviour of pea growers towards improved production technology. 2. To ascertain the association between attributes of pea growers and adoption behavior of improved pea production technology.

\section{Materials and Methods}

The present study was conducted in Jabalpur district of Madhya Pradesh because it is famous for pea cultivation in Madhya Pradesh. The Jabalpur district comprises of 7 blocks namely Jabalpur, Panagar, Kundam, Patan, Shahpura, Manjholi and Sihora, out of which Shahpura and Patan blocks were selected purposively on the basis of larger area coverage under pea crop and famous for pea cultivation. Out of which 10 villages were selected randomly for the study on the basis of maximum area covered under pea cultivation. A list of pea growing farmers of each selected village was prepared with the help of RAEO/RHEOs, out of which 15 farmers were randomly selected from each village. Thus, the total sample size was 300 for the study (150 farmers from Shahpura and 150 farmers from Patan block) Data were collected through personal interview with the help of pre-tested structured interview schedule. The respondents of the selected villages were the primary sources of data collection. The primary data were collected by the researcher by interviewing the selected respondents with the help of structured and pre-tested interview schedule. The secondary data were obtained from various government offices like District Agriculture Office, Sub-division Office, Block Development Office, and from magazines and publications etc. The data were recorded, classified and tabulated and appropriate statistical tools like mean, percentage, chisquare test etc. were applied according to the nature and demand of data. The Data collected were in front of qualitative as well as quantitative. The quantitative data were tabulated on the basis of approved categorization method.

\section{Results and Discussion}

Table 1 reveals that out of the total pea growers, 46.00 per cent had low knowledge, 
35.67 per cent had medium knowledge and 18.33 per cent were found in the high knowledge level categories. Thus, it can be concluded that the higher percentage of pea growers $(46.00 \%)$ were having low knowledge level about improved pea production technology.

Table 2 indicates the mean scores of knowledge obtained by the pea growers. It is obvious from the table the mean scores of various technical component of improved pea production were range from 2.82 to 27.16 . The technological components of pea production technology in which the pea growers were having mean score higher than the overall mean were seed selection, seed rate and treatment as it received $1^{\text {st }}$ rank, followed by
2,3,4 fertilizer management, insect management and seed sowing management. The technological components which have lower mean scores than the overall mean were harvesting management which received $5^{\text {th }}$ rank, followed by weed management field management, irrigation management and diseases management thus, it can be concluded that important technological components to the pea growers were:-1,2,3,4.

Table 3 indicates that out of the total pea growers, 41.33 per cent had low adoption, whereas 40.00 per cent had medium adoption and 18.67 per cent in high adoption category. It was found that higher percentage $(41.33 \%)$ of pea growers exhibited low adoption of improved pea production technology.

Table.1 Distribution of pea growers on the basis of their knowledge level about improved pea production technology

\begin{tabular}{|c|c|c|c|}
\hline S.no. & Knowledge level & $\begin{array}{c}\text { No of } \\
\text { respondents }\end{array}$ & percentage \\
\hline $\mathbf{1 .}$ & Low (Up to 44 scores) & 138 & $\mathbf{4 6 . 0 0}$ \\
\hline $\mathbf{2 .}$ & Medium (45 to 88 scores) & 107 & $\mathbf{3 5 . 6 7}$ \\
\hline $\mathbf{3 .}$ & High (89 to 132 scores) & $\mathbf{5 5}$ & $\mathbf{1 8 . 3 3}$ \\
\hline
\end{tabular}

\section{DISTRIBUTION OF PEA GROWERS ACCORDING TO THEIR KNOWLEDGE LEVEL}

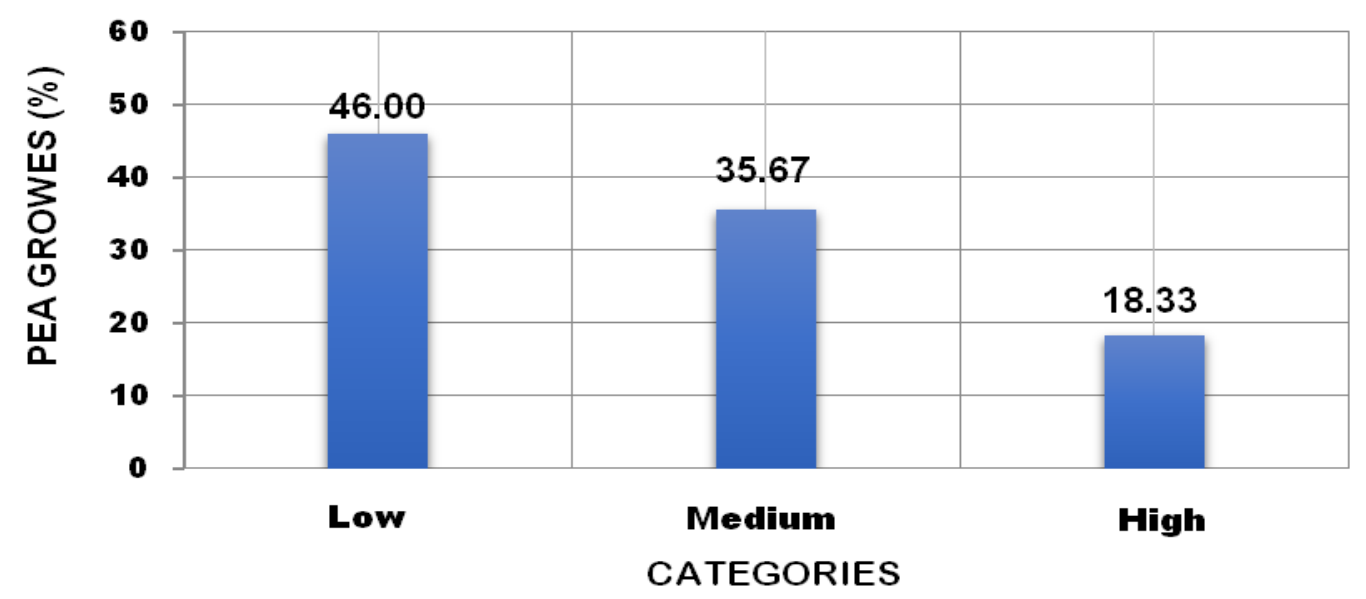


Table.2 Mean score of knowledge level of improved pea production technology among pea growers

\begin{tabular}{|c|l|c|c|}
\hline $\begin{array}{c}\text { S.No } \\
\text {. }\end{array}$ & Technology component & Mean & Rank \\
\hline 1. & Field management & 11.48 & VII \\
\hline 2. & Seed selection, seed rate and treatment & 27.16 & I \\
\hline 3. & Seed sowing management & 12.72 & IV \\
\hline 4. & Fertilizer management & 26.74 & II \\
\hline $\mathbf{5 .}$ & Irrigation management & 6.81 & VIII \\
\hline 6. & Weed management & 12.36 & VI \\
\hline 7. & Insect management & 19.77 & III \\
\hline 8. & Diseases management & 2.82 & IX \\
\hline 9. & Harvesting management & 12.29 & V \\
\hline & & $\mathbf{1 4 . 6 8}$ & \\
\hline
\end{tabular}

Table.3 Adoption behaviour of pea growers towards improved pea production

\begin{tabular}{|c|c|c|c|}
\hline $\begin{array}{c}\text { S. } \\
\text { No. }\end{array}$ & Categories & No. of respondents & Percentage \\
\hline $\mathbf{1 .}$ & $\begin{array}{c}\text { Low adoption } \\
\text { (Up to 44 scores) }\end{array}$ & 124 & $\mathbf{4 1 . 3 3}$ \\
\hline $\mathbf{2 .}$ & $\begin{array}{c}\text { Medium adoption } \\
\text { (45 to 88 scores) }\end{array}$ & 120 & $\mathbf{4 0 . 0 0}$ \\
\hline $\mathbf{3 .}$ & $\begin{array}{c}\text { High adoption } \\
\text { (89 to } \mathbf{1 3 2} \text { scores) }\end{array}$ & $\mathbf{5 6}$ & $\mathbf{1 8 . 6 7}$ \\
\hline
\end{tabular}

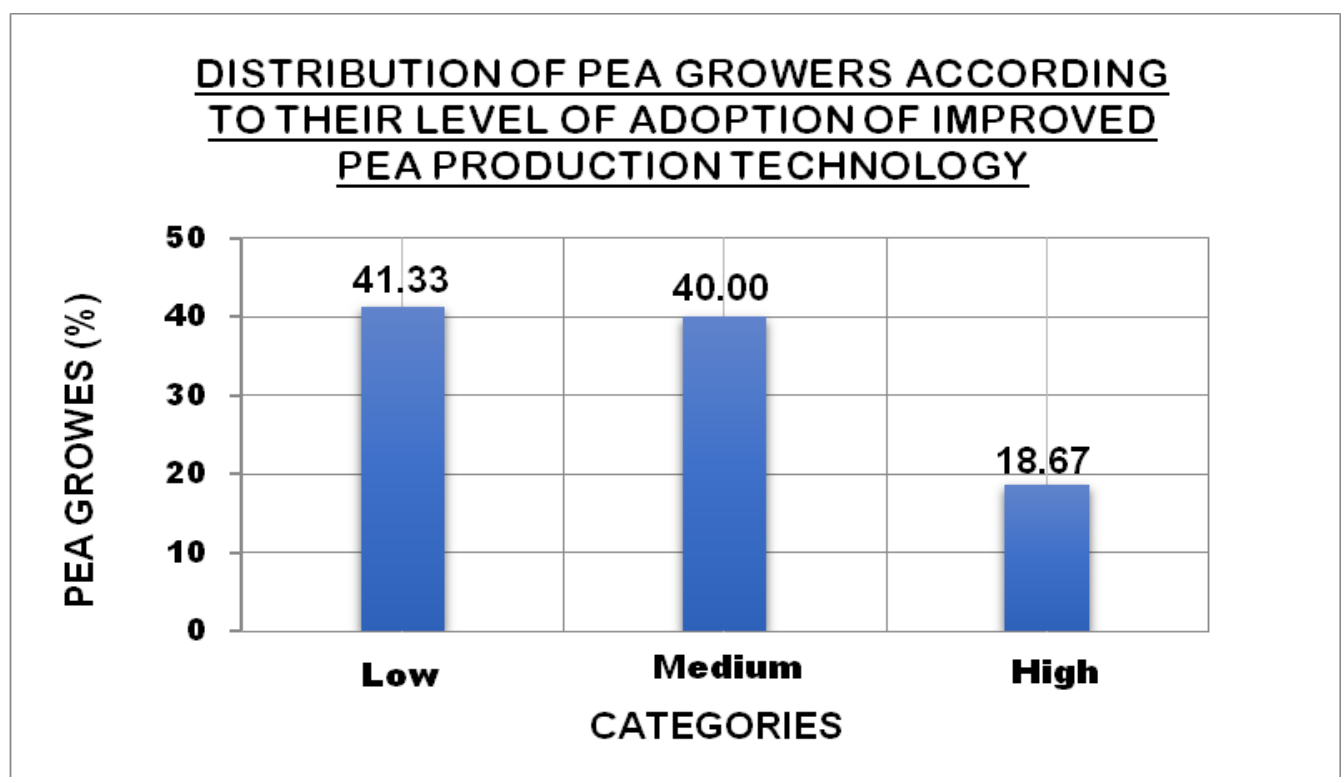


Table.4 Mean score of adoption behavior of improved pea production technology among pea growers

\begin{tabular}{|l|l|l|l|}
\hline S.No. & \multicolumn{1}{|c|}{ Technology component } & \multicolumn{1}{|c|}{ Mean } & \multicolumn{1}{|c|}{ Rank } \\
\hline $\mathbf{1 .}$ & Field management & 24.64 & II \\
\hline $\mathbf{2 .}$ & Seed selection, seed rate and treatment & 18.24 & III \\
\hline $\mathbf{3 .}$ & Seed sowing management & 25.89 & I \\
\hline $\mathbf{4 .}$ & Fertilizer management & 11.16 & V \\
\hline $\mathbf{5 .}$ & Irrigation management & 9.89 & VII \\
\hline $\mathbf{6 .}$ & Weed management & 10.82 & VI \\
\hline $\mathbf{7 .}$ & Insect management & 2.42 & IX \\
\hline $\mathbf{8 .}$ & Diseases management & 5.92 & VIII \\
\hline $\mathbf{9 .}$ & Harvesting management & 11.36 & IV \\
\hline & Overall mean(x) & $\mathbf{1 3 . 3 8}$ & \\
\hline
\end{tabular}

Table.5 Association between attributes of pea growers and their adoption behaviour

\begin{tabular}{|l|l|l|l|c|c|}
\hline $\begin{array}{l}\text { S. } \\
\text { No. }\end{array}$ & Variables & $\begin{array}{l}\text { Value } \\
\text { (Cal.) }\end{array}$ & $\begin{array}{l}\text { Value } \\
\text { (Tab.) }\end{array}$ & d.f. & Result \\
\hline $\mathbf{1 .}$ & Age & 17.377 & 9.49 & 4 & NS \\
\hline $\mathbf{2 .}$ & Education & 39.811 & 12.59 & 6 & S \\
\hline $\mathbf{3 .}$ & Caste & 00.995 & 13.3 & 4 & NS \\
\hline $\mathbf{4 .}$ & Size of Land holding & 19.706 & 9.49 & 4 & $\mathbf{S}$ \\
\hline $\mathbf{5 .}$ & Farm power & 25.344 & 9.49 & 4 & $\mathbf{S}$ \\
\hline $\mathbf{6 .}$ & Area covered under pea & 11.76 & 9.49 & 4 & $\mathbf{S}$ \\
\hline $\mathbf{7 .}$ & Experience of pea growing & 36.136 & 13.3 & 4 & $\mathbf{S}$ \\
\hline $\mathbf{8 .}$ & Annual income & 11.78 & 9.49 & 4 & $\mathbf{S}$ \\
\hline $\mathbf{9 .}$ & Social participation & 13.548 & 9.49 & 4 & $\mathbf{S}$ \\
\hline $\mathbf{1 0 .}$ & Knowledge level & 2.68 & 3.84 & 1 & $\mathbf{S}$ \\
\hline $\mathbf{1 1}$. & Scientific orientation & 9.203 & 9.49 & 4 & $\mathbf{S}$ \\
\hline $\mathbf{1 2 .}$ & Training needs & 28.622 & 9.49 & 4 & $\mathbf{S}$ \\
\hline $\mathbf{1 3 .}$ & Extension participation & 84.336 & 9.49 & 4 & $\mathbf{S}$ \\
\hline $\mathbf{1 4 .}$ & Source of Information & 8.479 & 9.49 & 4 & NS \\
\hline $\mathbf{1 5}$ & Marketing orientation & $\mathbf{2 8 . 0 2 4}$ & $\mathbf{9 . 4 9}$ & $\mathbf{4}$ & $\mathbf{S}$ \\
\hline
\end{tabular}

Table 4 indicates the mean scores of adoption obtained by the pea growers. It is obvious from the table the mean scores of various technical component of improved pea production were range from 2.42 to 25.89 . The technological components of pea production technology in which the pea growers were having mean score higher than the overall mean were seed sowing management as it received $1^{\text {st }}$ rank, followed by 2,3,4 field management, seed selection, seed rate and treatment, harvesting management. The technological components which have lower mean scores than the overall mean were fertilizer management which received $5^{\text {th }}$ rank, followed by weed management, irrigation management, diseases management and insect management. Thus, it 
can be concluded that important technological components to the pea growers were $1,2,3$ and 4 .

Association between attributes of pea growers and their adoption behaviour

The association between various attributes of pea growers like socio-personal, psychological and communicational attributes with the adoption behaviour were worked out, which showed that age, caste, area covered under pea and source of information were found non-significant, while all other remaining attributes of vegetable growers., education, size of land holding, experience of pea growing, income, scientific orientation, source of information, extension participation, market orientation, training need, social participation and farm power were found to be significantly associated with adoption behaviour, it was found that higher percentage $(41.33 \%)$ of pea growers exhibited low adoption of improved pea production technology (Table 5). The association between various attributes of pea growers like socio-personal, psychological and communicational attributes with the adoption behaviour were worked out, which showed that age, caste, area covered under pea and source of information were found nonsignificant, while all other remaining attributes of vegetable growers i.e., education, size of land holding, experience of pea growing, income, knowledge level, scientific orientation, source of information, extension participation, market orientation, training need, social participation and farm power were found to be significantly associated with adoption behaviour.

\section{References}

Aske, B.S. (2007). A study on adoption behavior of tribal farmers in respect of soybean production technology of urban block of Dhar district, M.P. M.Sc. (Ag.) Thesis (unpublished), JNKVV, Jabalpur.

Barodia, A.R. (2005). A study on adoption behaviour of vegetable growers in relation to improved technology in Phandana block of Bhopal district (M.P.). M.Sc. (Ag.) Thesis (unpublished), JNKVV, Jabalpur.

Bhople, R.S. and P.S. Sinde (2002). Impact of vegetable cultivation, income organized by KVK and vegetable growers of Shabhangi Kbonde. Maha. J. Extn. Edu., Vol. XIX, No.1, p.81.

Kushwaha, Vikash Babu (2008). A study on adoption behaviour of farmers in relation to cultivation of totmato crop in Sanchi block of Raisen district (M.P.). M.Sc. (Ag.) Thesis (unpublished),

JNKVV, Jabalpur. Lokhande, V.K. (2010). A study on adoption behaviour of tomato growers in relation to improved production technology in Chhindwara block of Chhindwara district (M.P.). M.Sc. (Ag.) Thesis (unpublished), JNKVV, Jabalpur.

National horticulture board (2014-15) nhb.gov.in

Thombre, B.M., Bhangare, Y.C. and Suradkar, D.D. (2014). Adoption of improved cultivation practices of pigeonpea by farmers. Agric. Update, 9 (1): 111-114.

\section{How to cite this article:}

Tiwari Abha, Markam Neha and Dubey, M.K. 2019. Factors Responsible for Adoption of Improved Pea Production Technology among the Pea Growers. Int.J.Curr.Microbiol.App.Sci. 8(03): 933-938. doi: https://doi.org/10.20546/ijcmas.2019.803.111 